\title{
Full Disclosure Policy (FDP) Compliance of the Davao del Norte Province at the FDP Portal
}

\author{
Glenne B. Lagura, Marilou D. Junsay \& Edgardo M. Santos \\ Institute of Management, Governance and Continuing Studies \\ Davao del Norte State College \\ 8105 New Visayas, Panabo City, Davao del Norte, Philippines \\ ORCID No. 0000-0003-4142-2771 \\ E-mail: glenne.lagura@dnsc.edu.ph
}

Received: August 4, 2017 Accepted: August 24, 2017 Online published: September 1, 2017 doi:10.5296/jpag.v7i3.11638

URL: https://doi.org/10.5296/jpag.v7i3.11638

\begin{abstract}
The study evaluated the availability of the financial transactions and procurement reports in the government portal of all the 11 Local Government Units (LGUs) under the Province of Davao del Norte which specifically determined the extent of its implementation of e-Governance particularly in implementing the Full Disclosure Policy (FDP) as a practice of transparency. In particular, the assessment was done to verify if the following reports were uploaded in the portal: (a) Budget Reports; (b) Procurement Reports; (c) Special Purpose Fund Reports. Fourteen (14) relevant reports were queried at the portal as accessed at http://fdps.blgs.gov.ph/ from year 2012 to 2013. Results were initially obtained through an assessment done by the researchers in checking into the availability of the inquired reports at the portal. Preliminary findings were triangulated as a group of MPA students verified the initial results. Quantitative tools such as frequency counts, means and percentages were employed to know the available reports. Findings showed that there was an increase of compliance percentage for the LGUs of Asuncion, New Corella, San Isidro and Sto. Tomas while there was a noticeably slight decrease of compliance for the rest of the LGUs. Moreover, Budget Reports were the most complied while Procurement Reports were the least complied. The study concludes that while all LGUs have utilized the portal through submission of the reports, other factors affecting prompt and complete compliance and distance and income classification should be looked into. It is suggested in the study that each LGU should maximize the adoption and utilization of the government portal as a medium in promoting transparency and accountability as a practice of good governance.
\end{abstract}


Keywords: Transparency, Full Disclosure Compliance, e-Governance, Good Governance

\section{Introduction}

Before the advent of the Information and Communication Technologies (ICTs), and prior to its rampant utilization, the once considered classified documents of the government such as budgets and spending were unreachable to the general public. Now, confidentiality and inaccessibility of such documents are no longer the case since the evolving trend is how the government should look into improving efficient and effective public service and promotion of transparency through the use of ICTs; this is the so called e-Governance.

As a mark of the eminent increase and the advancement of e-Governance, according to the UN e-Government Survey (2010), most countries are going beyond basic websites through providing national portals for the citizens to be connected to government services.

Such scenario is observable in the country Philippines wherein during also in the year 2010 a national policy initiated from the Department of Interior and Local Government (DILG) which mandates all local governments to post all financial transactions and procurement at the conspicuous places of the locality - the Full Disclosure Policy - has been implemented- . This was spearheaded by the late DILG Secretary, Jesse Robredo to increase transparency and to practice the culture of accountability.

In the report of Ong (2012), as of June 2012, as obtained from the Pulse Asia and Social Weather Stations survey, 1,697 or $99 \%$ of LGUs had complied with the policy. To strengthen the implementation of the FDP, the Full Disclosure Policy Portal (FDPP) was establish last 2012 as accessible in the website address http://fdpp.blgs.gov.ph/. This enables the public to view, download and print LGU financial documents to allow their constituents to understand how their local governments budget and spend for public services. Such compliance of posting the required reports by the FDP heightened citizen participation and civic engagement (Berner, 2011). It could also imply that the city is enjoying good governance and healthier economic and social outcomes as there are referred as interrelated components according to You and Lee (2007).

To encourage participation of the Local Government Units (LGUs), FDP compliance became a requirement in the conferment of the Seal of Good Housekeeping (SGH) as a reward will be given to those LGUs which promotes honesty and excellence in local governance. For non-compliance of the required submission and postings of reports, the concerned local officials are subjected to suspension or removal from office on the ground of negligence or dereliction of duty in accordance with section 60 of the Local Government Code.

Davao del Norte State College (DNSC), as an institution which promotes good governance by offering the relevant course - Bachelor of Public Administration and as a partner institution of the province - the Davao del Norte Learning Institute, it is imperative for the academe to pursue relevant researches which would benefit the whole citizenry of the province.

From the presented scenario, this warrants the proponents of this study to conduct an 


\section{Macrothink}

assessment regarding the compliance of all the municipalities in the province of Davao del Norte in posting the required reports by the FDP at the FDP portal.

Such proposed study supports the thrust of Pres. Benigno C. Aquino III as the current Chief Executive of the country prioritizes actions which will lead to anti-corruption, transparent, accountable and participatory governance. In addition, this is aligned to the governance priority research agenda of the Davao Region since part of the priority research areas for the macro-economy and general public administration are managing the fight against corruption and the effective utilization of ICTs. Lastly, this corresponds to the priority research areas in education wherein the Commission on Higher Education (CHEd) emphasized policy oriented studies in the dimension of policy formulation, implemented, monitoring and evaluation to be undertaken by the researchers.

\section{Objectives of the Study}

Generally, the study was conducted in order to find out the compliance of the municipalities/cities in the Province of Davao del Norte in posting the reports required by the Full Disclosure Policy portal.

Specifically, the study was sought to find out the availability of the following reports at the FDP portal:

1. Budget Reports;

a) Annual Budget such as;

b) Statement of Debt Services;

c) Statement of Receipts and Expenditures; and

d) Quarterly Statement of Cash Flows.

2. Procurement Reports such as; and

a) Annual Procurement Plan;

b) Quarterly Items to Bid;

c) Quarterly Bid Results on Civil Works, Goods and Services; and

d) Quarterly Abstract of Bids as Calculated.

3. Special Purpose Fund Reports such as:

a) SEF Income and Expenditures Estimates;

b) SEF Utilization;

c) Annual GAD Accomplishment Report;

d) Trust Fund Utilization;

e) $20 \%$ Component of the IRA Utilization; and

f) Local DRMM Fund Utilization.

\section{Theory Base}

This study is primarily anchored to the Memorandum Circular No. 2010-83 and 2011-134 or the Full Disclosure of Local Budget and Finances, and Bids and Public Offerings, issued by the late Department of the Interior and Local Government Secretary Jesse M Robredo. The memorandum requires all local chief executives to post the required documents in conspicuous places within public buildings in the locality, or in print media of community or 
general circulation and on their websites. In the event that a local government does not have a website, specific financial documents and transactions are to be posted in the DILG Office Website or the Full Disclosure Policy Portal.

This policy is not a new rule since this fully abides the following legal laws mandates which requires its implementation: Section 352 of the Local Government Code, Republic Act No. 9184- known as the Government Procurement Reform Act, Section 90 of Republic Act No. 10147 (General Appropriation Act) FY 2011- "Use and Disbursement of Internal Revenue Allotment of LGUs" and the Commission on Audit Internal Memorandum.

\section{Conceptual Framework}

The conceptual framework formulated determines the compliance of the municipalities in the province of Davao del Norte in implementing the Full Disclosure Policy (FDP) through posting the required reports at the FDP portal.

There are two (2) main variables available; the independent variable which comprise the posted reports at the FDP portal and the dependent variable which are the concerned municipalities in the province (see Figure1).

\begin{tabular}{|c|c|}
\hline & LGUs of Davao del Norte: \\
\hline & 1. Asuncion \\
\hline & 3. Kanalong \\
\hline \multirow{7}{*}{$\begin{array}{l}\text { Posted Reports at FDP Portal } \\
\text { a. Budget Reports } \\
\text { b. Procurement Reports } \\
\text { c. Special Fund Reports }\end{array}$} & 4. New Corella \\
\hline & 5. Panabo \\
\hline & 6. Island Garden City of Samal \\
\hline & 7. Sto. Tomas \\
\hline & 8. Tagum \\
\hline & 9. Talaingod \\
\hline & 10. Braulio E. Duiali \\
\hline
\end{tabular}

Figure 1. Conceptual Framework Showing the Variables of the Study

\section{Methodology}

This study was predominantly concerned in attaining the answers in the questions "what is the update?" and "do they comply?" thus this is an evaluative type of research. According to Weiss (1998), evaluation is the systematic assessment of the operation and/or the outcomes of a program or policy, compared to a set of explicit or implicit standards, as a means of contributing to the improvement of the program or policy. This study used complete enumeration of the municipalities in the province of Davao del Norte as well as the reports required by the FDP to be posted at the FDP portal as posted from two years' time 2012-2013. Secondary data were obtained at the FDP portal which was accessed at 
http://fdpp.blgs.gov.ph/. Descriptive statistics were employed in the final analysis.

\section{Results}

\section{Budget Reports}

In this section, four (4) different budgets reports were inquired that covers Annual Budget, Statement of Debt Services, Statement of Receipts and Expenditures, which are posted once a year, and the statement of cash flows, which must be posted quarterly.

Presented in Table 1 is the compliance report of the eleven (11) LGUs in the Province of Davao del Norte in posting the required budget reports at the FDP portal in the year 2012. As to the total reports required, there are 7 relevant budget reports inquired in the particular year wherein it is noteworthy to discuss that 8 out of 11 concerning LGUs were able to upload $100 \%$ of all the required reports at the portal.

The practice of transparency as indicated by these LGUs through making budgets and finances available in the portal validates Berner (2001) that this is a form of citizen participation. It could imply that the city is enjoying good governance and better economic and social outcomes as these are referred as interrelated components according to You and Lee (2007).

Kapalong, Sto. Tomas and San Isidro were the only municipalities that were not able to fully comply obtaining $71 \%, 57 \%$ and $43 \%$ as the percentage of compliance respectively. In the idea of Epal and Linden (2010), inability to provide reports relating to budgets and expense could heighten corruption and misuse of fund. In this particular case, the concerning LGUs must exert more effort in the pursuit of transparency by divulging the allocated budget and incurred expenses through posting these in the web portal.

Table 1. Budget Reports Available at the FDP Portal, 2012

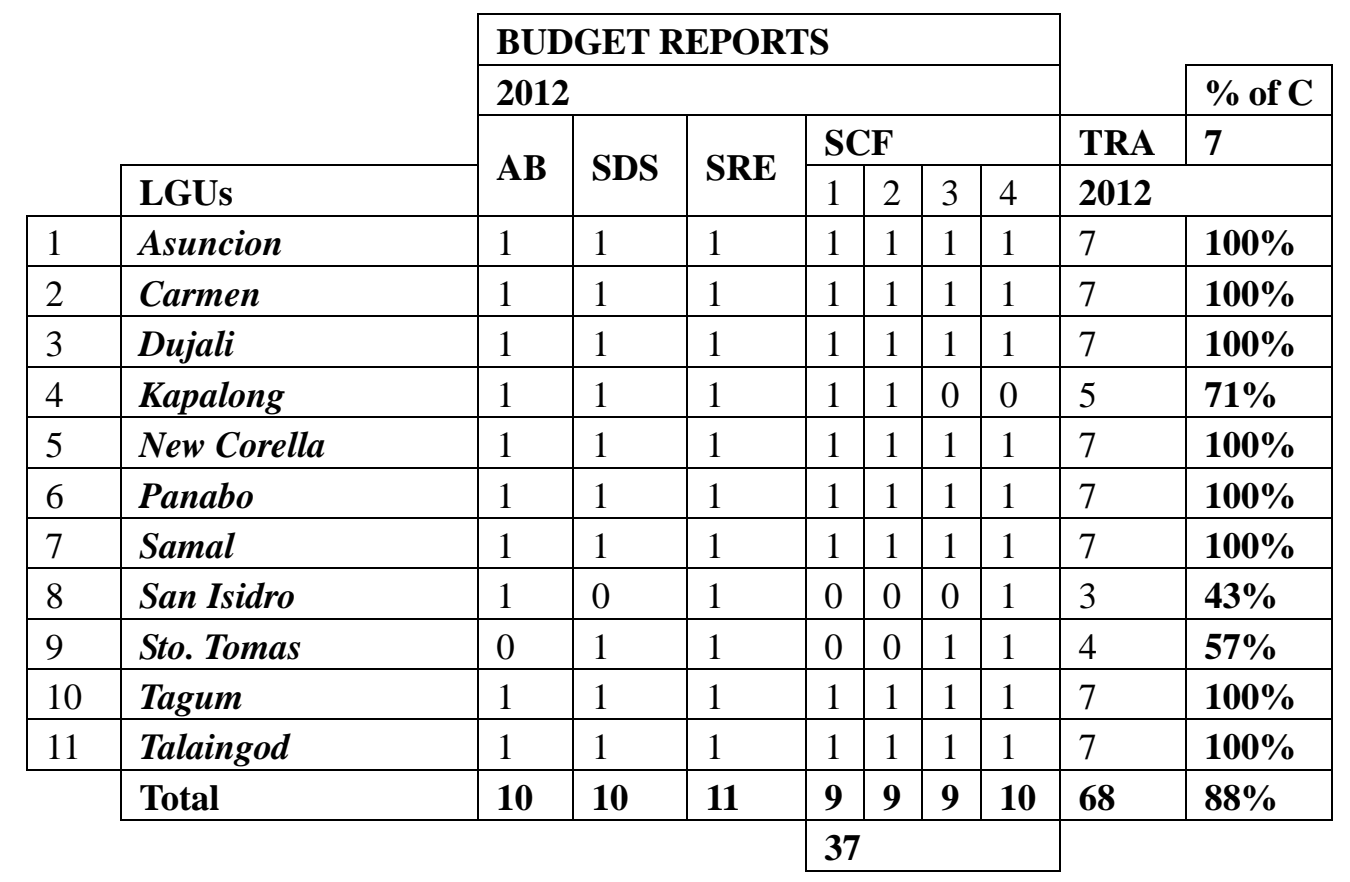




\section{$\triangle{ }_{\text {Mnstitute }}^{\text {Macrothink }}$}

Legend:

AB

Annual Budget

SDS

Statement of Debt Services

SRE Statement of Receipts and Expenditures

SCF Quarterly Statement of Cash Flows

TRA Total Reports Available

\% ofC Percentage of Compliance

To continue, all of the municipalities were able to upload the Statement of Receipts and Expenditures at the FDP portal in the year 2012. Overall, the LGUs in the Province of Davao del Norte obtained $88 \%$ as the compliance percentage in posting the required budget reports at the portal.

For the availability of Budget Reports in the year 2013, it can be depicted in Table 2 that all of the LGUs in the province except for the municipality of Kapalong (57\%) were able to make available all the 7 reports required in the concerning year which equates to $100 \%$ full compliance.

Table 2. Budget Reports Available at the FDP Portal, 2013

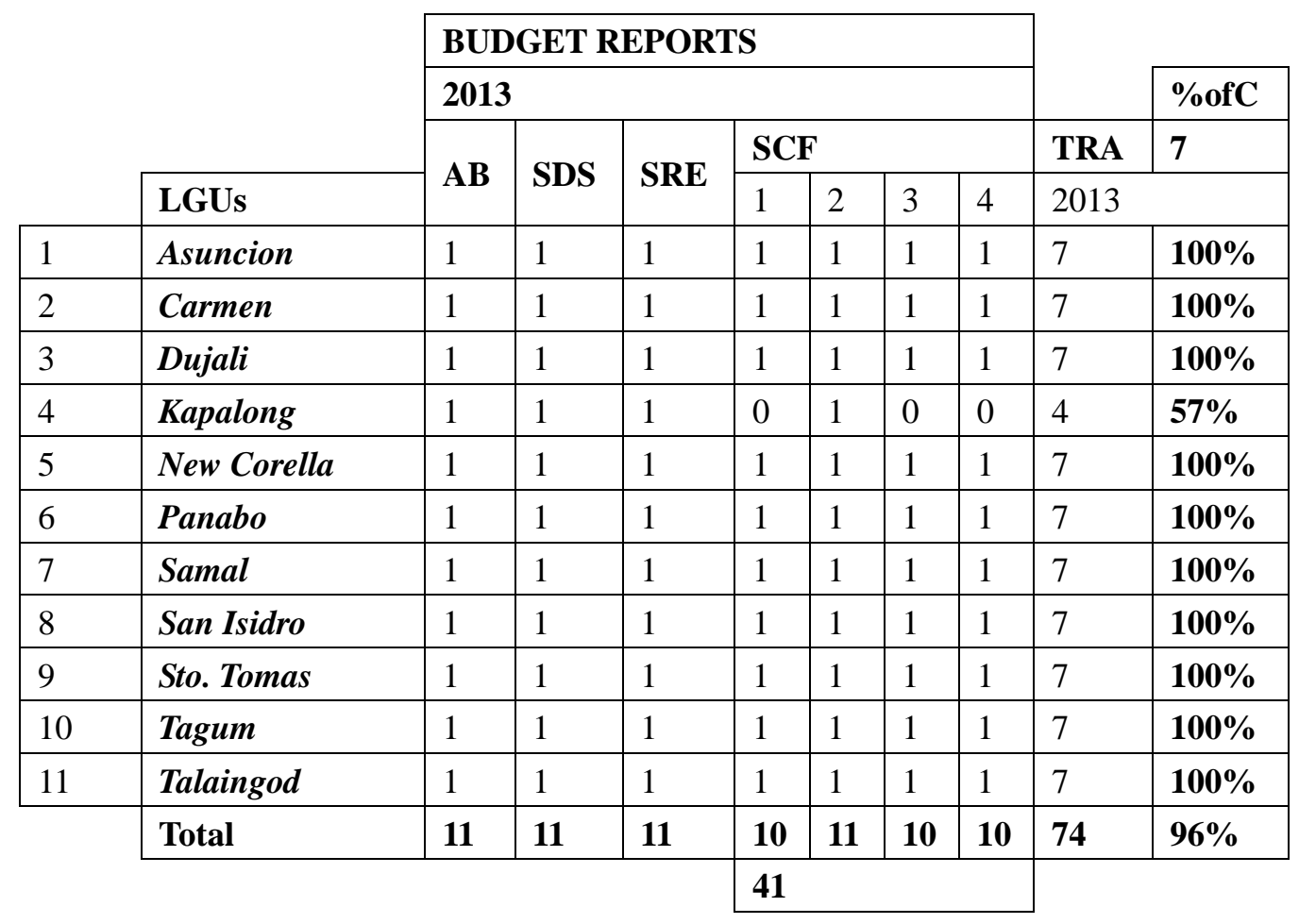

As to the specific relevant reports, the 3 reports which have to be uploaded annually, to name: Annual Budget, Statement of Debt Services, Statement of Receipts and Expenditures were fully complied by the LGUs and only on the second quarter wherein the Statements of Cash Flows were made to be completely available. To conclude, the overall percentage of compliance of the LGUs under the Province of Davao del Norte in posting the relevant Budget Reports at the FDP portal in the year 2013 is $96 \%$. 


\section{Macrothink Institute ${ }^{\mathrm{TM}}$}

From the aforementioned discussions as to the compliance in posting the required Budget Reports at the FDP portal and as can be seen in Figure 2, it can be depicted that comparably, from year 2012 the compliance of the LGUs is increasing in the year 2013 except for the municipality of Kapalong which is also true in the overall compliance in the year 2012 and 2013.

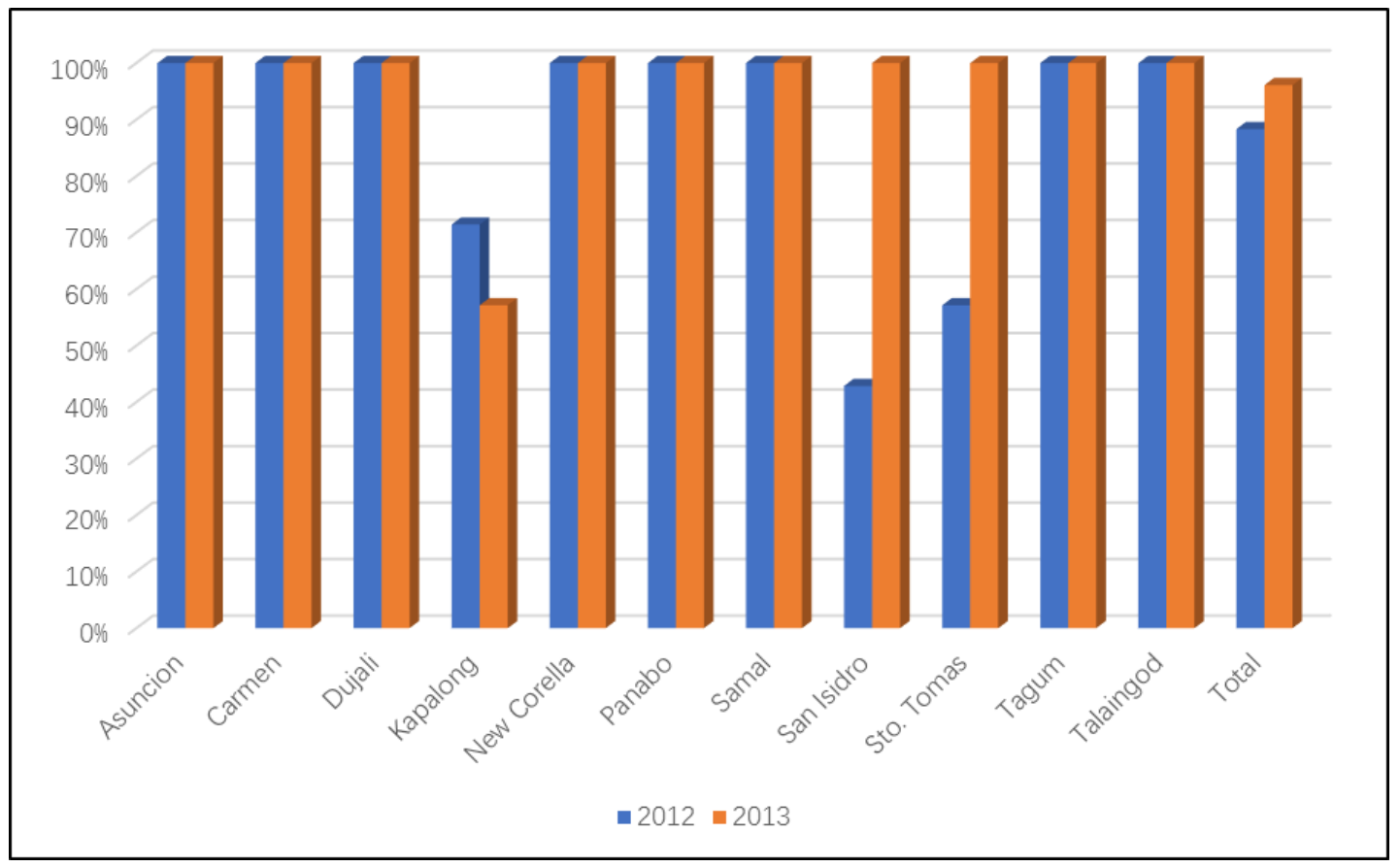

Figure 2. Comparison on Budget Reports Compliance, 2012-2013

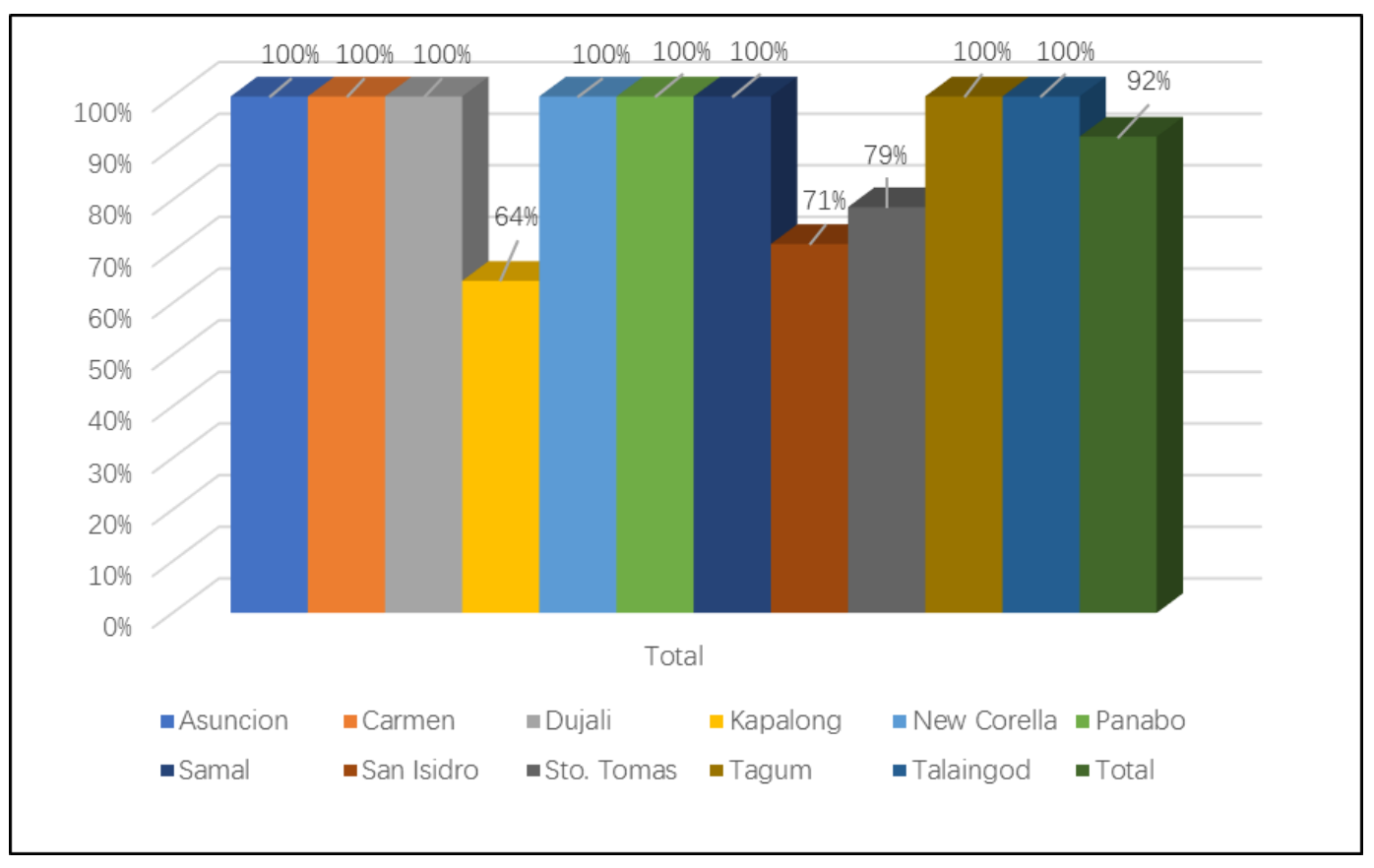

Figure 3. Overall Budget Reports Compliance 


\section{Macrothink}

As to the overall compliance report, in terms of posting the relevant Budget Reports, as observed in Figure 3, out of 11 LGUs, 8 of those were able to comply $100 \%$ of the required documents. The other LGUs such as Sto. Tomas, San Isidro and Kapalong were partially compliant having the following respective compliance percentage: $79 \%, 71 \%$ and $64 \%$. In totality, the LGUs of the Province of Davao del Norte got $92 \%$ compliance in posting the required Budget Reports in the year 2012 and 2013 at the FDP portal. For Siar (2007) stated that the availability of the relevant budget reports could raise the citizens' political awareness in the budget making and spending which attributable to the active involvement of the citizens in the political context of the LGUs.

As a support from the latter statement, making the information available inquired regarding the budgets allocated in the LGUs entices the general citizen to be an active participant in the context of budget preparation thus entices citizens' engagement in the budget process and enhances citizens' participation.

\section{Procurement Reports}

The subsequent discussions which are tackled in this section reveal the compliance of the LGUs in making the four (4) required Procurement reports available posted at the FDP portal. One of these reports, the Annual Procurement Plan is to be posted once a year and the other remaining reports like the Items to Bid, Bid Results on Civil Works, Goods and Services and Abstract of Bids as Calculated are to be posted quarterly. In this particular section, there were 13 reports inquired each year which totaled to 26 reports from 2012- 2013.

Illustrated in Table 3 is the compliance of the LGUs in posting the Procurement Reports in the year 2012 at the FDP portal. As it can be observed, 5 LGUs namely the municipality of Carmen, Dujali and the city of Panabo, Samal and Tagum were able to fully comply the posting of the 13 required documents at the portal. This is followed by the municipalities of Asuncion and New Corella which comply 85\%, municipality of Kapalong and Talaingod which both comply $69 \%$ and Sto. Tomas and San Isidro having the respective compliance percentage of $15 \%$ and $8 \%$.

To sum up, the overall compliance of the LGUs in the particular year as to making the Procurement Reports available is $76 \%$. 
Table 3. Procurement Reports Available at the FDP Portal, 2012

\begin{tabular}{|c|c|c|c|c|c|c|c|c|c|c|c|c|c|c|c|c|}
\hline & \multirow[b]{4}{*}{ LGUs } & \multicolumn{13}{|c|}{ PROCUREMENT REPORTS } & \multirow[b]{3}{*}{ TRA } & \multirow{3}{*}{$\begin{array}{l}\text { \% ofC } \\
13\end{array}$} \\
\hline & & \multicolumn{13}{|l|}{2012} & & \\
\hline & & \multirow{2}{*}{ APP } & \multicolumn{4}{|c|}{ ITB } & \multicolumn{4}{|c|}{ BR } & \multicolumn{4}{|c|}{$\mathbf{A B C}$} & & \\
\hline & & & 1 & 2 & 3 & 4 & 1 & 2 & 3 & 4 & 1 & 2 & 3 & 4 & \multicolumn{2}{|l|}{2012} \\
\hline 1 & Asuncion & 1 & 1 & 1 & 0 & 0 & 1 & 1 & 1 & 1 & 1 & 1 & 1 & 1 & 11 & $85 \%$ \\
\hline 2 & Carmen & 1 & 1 & 1 & 1 & 1 & 1 & 1 & 1 & 1 & 1 & 1 & 1 & 1 & 13 & $100 \%$ \\
\hline 3 & Dujali & 1 & 1 & 1 & 1 & 1 & 1 & 1 & 1 & 1 & 1 & 1 & 1 & 1 & 13 & $100 \%$ \\
\hline 4 & Kapalong & 1 & 0 & 0 & 0 & 0 & 1 & 1 & 1 & 1 & 1 & 1 & 1 & 1 & 9 & $69 \%$ \\
\hline 5 & New Corella & 1 & 1 & 1 & 1 & 1 & 1 & 0 & 1 & 1 & 1 & 0 & 1 & 1 & 11 & $85 \%$ \\
\hline 6 & Panabo & 1 & 1 & 1 & 1 & 1 & 1 & 1 & 1 & 1 & 1 & 1 & 1 & 1 & 13 & $100 \%$ \\
\hline 7 & Samal & 1 & 1 & 1 & 1 & 1 & 1 & 1 & 1 & 1 & 1 & 1 & 1 & 1 & 13 & $100 \%$ \\
\hline 8 & San Isidro & 0 & 0 & 0 & 0 & 0 & 0 & 0 & 0 & 0 & 0 & 0 & 0 & 1 & 1 & $8 \%$ \\
\hline 9 & Sto. Tomas & 1 & 0 & 0 & 0 & 0 & 0 & 0 & 0 & 0 & 0 & 0 & 1 & 0 & 2 & $15 \%$ \\
\hline 10 & Tagum & 1 & 1 & 1 & 1 & 1 & 1 & 1 & 1 & 1 & 1 & 1 & 1 & 1 & 13 & $100 \%$ \\
\hline \multirow[t]{2}{*}{11} & Talaingod & 1 & 0 & 0 & 0 & 0 & 1 & 1 & 1 & 1 & 1 & 1 & 1 & 1 & 9 & $69 \%$ \\
\hline & Total & 10 & 7 & 7 & 6 & 6 & 9 & 8 & 9 & 9 & 9 & 8 & 10 & 10 & 108 & $76 \%$ \\
\hline
\end{tabular}

Legend:
APP Annual Procurement Plan
ITB Quarterly Items to Bid
BR Quarterly Bid Results on Civil Works, Goods and Services
ABC Quarterly Abstract of Bids as Calculated
TRA Total Reports Available
\%ofC Percentage of Compliance

For the compliance of posting Procurement Reports in the year, it can be noted that none of the LGUs were able to upload completely the required documents in 2013 (see Table 4). Since as can be seen in the table, both in the last quarter of the document Items to Bid and Abstract of Bids as Calculated, all of the LGUs were not able to upload the certain reports. Thus the highest compliance percentage is $85 \%$ as obtained by the municipalities of Dujali, San Isidro, and Talaingod and the cities of Panabo, Samal and Tagum. After such, it was followed by the municipality of New Corella for having $77 \%$ compliance percentage, municipalities of Asuncion and Carmen which has a percentage of compliance of $69 \%$, then the municipality of Santo Tomas and Kapalong obtaining 62\% and 54\% respectively.

It is observable also that all of the LGUs were able to provide the Annual Procurement Plan report at the portal as well as the Items to Bid on the first quarter. Overall, the LGUs obtained $76 \%$ as the compliance in posting the specific reports in the year 2013. 


\section{Macrothink}

Table 4. Procurement Reports Available at the FDP Portal, 2013

\begin{tabular}{|c|c|c|c|c|c|c|c|c|c|c|c|c|c|c|c|c|}
\hline & \multirow[b]{4}{*}{ LGUs } & \multicolumn{13}{|c|}{ PROCUREMENT REPORTS } & \multirow[b]{3}{*}{ TRA } & \multirow{3}{*}{\begin{tabular}{|l|} 
\% ofC \\
13 \\
\end{tabular}} \\
\hline & & \multicolumn{13}{|c|}{2013} & & \\
\hline & & \multirow{2}{*}{ APP } & \multicolumn{4}{|c|}{ ITB } & \multicolumn{4}{|c|}{ BR } & \multicolumn{4}{|c|}{$\mathbf{A B C}$} & & \\
\hline & & & 1 & 2 & 3 & 4 & 1 & 2 & 3 & 4 & 1 & 2 & 3 & 4 & \multicolumn{2}{|l|}{2013} \\
\hline 1 & Asuncion & 1 & 1 & 1 & 1 & 0 & 0 & 1 & 1 & 1 & 0 & 1 & 1 & 0 & 9 & $69 \%$ \\
\hline 2 & Carmen & 1 & 1 & 0 & 1 & 0 & 1 & 1 & 1 & 1 & 1 & 0 & 1 & 0 & 9 & $69 \%$ \\
\hline 3 & Dujali & 1 & 1 & 1 & 1 & 0 & 1 & 1 & 1 & 1 & 1 & 1 & 1 & 0 & 11 & $85 \%$ \\
\hline 4 & Kapalong & 1 & 1 & 1 & 0 & 0 & 1 & 1 & 0 & 0 & 1 & 1 & 0 & 0 & 7 & $54 \%$ \\
\hline 5 & New Corella & 1 & 1 & 1 & 1 & 0 & 1 & 0 & 1 & 1 & 1 & 1 & 1 & 0 & 10 & $77 \%$ \\
\hline 6 & Panabo & 1 & 1 & 1 & 1 & 0 & 1 & 1 & 1 & 1 & 1 & 1 & 1 & 0 & 11 & $85 \%$ \\
\hline 7 & Samal & 1 & 1 & 1 & 1 & 0 & 1 & 1 & 1 & 1 & 1 & 1 & 1 & 0 & 11 & $85 \%$ \\
\hline 8 & San Isidro & 1 & 1 & 1 & 1 & 0 & 1 & 1 & 1 & 1 & 1 & 1 & 1 & 0 & 11 & $85 \%$ \\
\hline 9 & Santo Tomas & 1 & 1 & 0 & 1 & 0 & 0 & 1 & 1 & 1 & 0 & 1 & 1 & 0 & 8 & $62 \%$ \\
\hline 10 & Tagum & 1 & 1 & 1 & 1 & 0 & 1 & 1 & 1 & 1 & 1 & 1 & 1 & 0 & 11 & $85 \%$ \\
\hline \multirow[t]{2}{*}{11} & Talaingod & 1 & 1 & 1 & 1 & 0 & 1 & 1 & 1 & 1 & 1 & 1 & 1 & 0 & 11 & $85 \%$ \\
\hline & Total & 11 & 11 & 9 & 10 & 0 & 9 & 10 & 10 & 10 & 9 & 10 & 10 & 0 & 109 & $76 \%$ \\
\hline
\end{tabular}

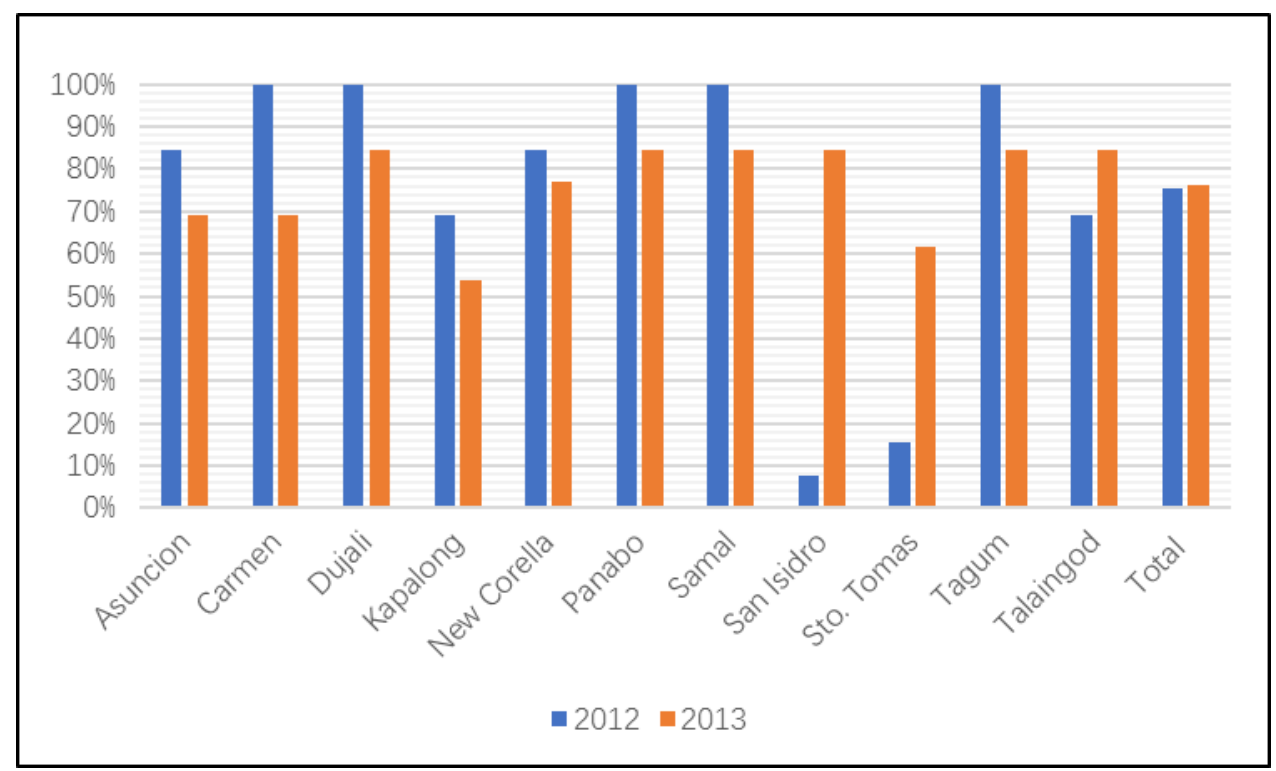

Figure 4. Comparison on Procurement Reports Compliance, 2012-2013

To have a comparative view, provided in Figure 4 is the percentage of compliance of the LGUs from 2012-2013. As to the trend, it can be observed that the compliance is not increasing except for the municipalities of San Isidro, Sto. Tomas, and Talaingod.

Shown in Figure 5 is the overall compliance of the LGUs in posting the Procurement Reports at the FDP portal. The municipality of Dujali, and the cities of Panabo, Samal, and Tagum obtained $92 \%$ as the compliance percentage. It was followed by the municipality of Carmen which complies $85 \%$ of the required reports, then the municipality of New Corella $-81 \%$, 


\section{Macrothink}

Journal of Public Administration and Governance

ISSN 2161-7104

2017, Vol. 7, No. 3

Asuncion and Talaingod which both have $77 \%$ compliance. Then, the Municipalities of Kapalong, San Isidro, and Sto. Tomas have respective percentage compliance of $62 \%, 46 \%$ and $38 \%$. Overall, a percentage rating of $76 \%$ was obtained in computing the average compliance of the LGUs in the Province of Davao del Norte in posting the required Procurement Reports at the portal.

LGUs should strive to provide concerning reports relevant to procurement transactions as stressed by Affisco and Soliman (2006) and Al-adawi, Yousafzai and Pallister (2005), that aside from the fact that the availability of these reports means fewer trips to government offices involved, this adds convenience to the citizens at the same time saves time and resources in availing the services.

The slight provision of the above information limits the citizen to be an active participant in deriving a decision which can bring advantageous social change and more efficient benefits for the rest of the society (Nelson and Wright, 1995; Beirle, 1999 as cited by Irvin et. al, 2004).

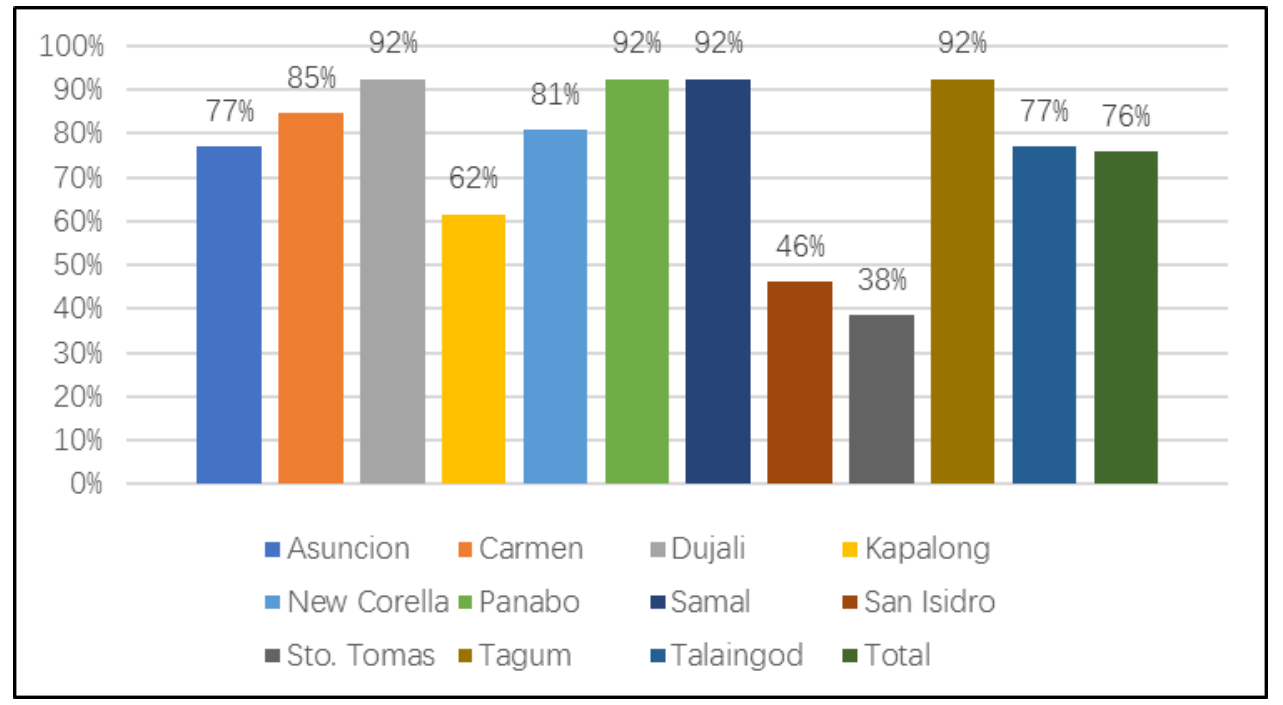

Figure 5. Overall Procurement Reports Compliance

\section{Special Purpose Fund Reports}

Six (6) reports were inquired in this particular section under the Special Purpose Fund Reports. Annually, these are SEF Income and Expenditures Estimates and the Gender and Development Accomplishment Report whereas quarterly, the SEF Utilization, Trust Fund Utilization, 20\% Component of IRA Utilization and Local DRRM Fund Utilization are inquired. Thus 18 documents are to be made available each year pertaining to these Special Purpose Fund Reports. A total of 32 reports were queried in this particular section.

As illustrated in Table 5, the table shows the availability of the concerning reports in the year 2012 as uploaded at the FDP portal. Six (6) LGUs were able to upload completely the 18 reports required with the totality of $100 \%$ compliance. These were the municipalities of Carmen, Dujali and Talaingod and the cities of Panabo, Samal and Tagum. Next are the municipalities of Asuncion and New Corella which obtained 83\% compliance. The 


\section{Macrothink}

Journal of Public Administration and Governance

ISSN 2161-7104

2017, Vol. 7, No. 3

municipality of Kapalong likewise got $50 \%$ compliance and municipalities of San Isidro and Sto. Tomas got $44 \%$ compliance.

Still in the year 2012, all the LGUs were able to upload the SEF Income and Expenditures Estimates and the fourth quarter report of the Local DRRM Fund Utilization. The overall compliance of the LGUs in posting the Special Purpose Fund Reports in the year 2012 is $82 \%$.

Table 5. Special Purpose Fund Reports Available at the FDP Portal, 2012

\begin{tabular}{|c|c|c|c|c|c|c|c|c|c|c|c|c|c|c|c|c|c|c|c|c|c|c|}
\hline & \multicolumn{18}{|c|}{ SPECIAL PURPOSE FUND REPORTS } & & & \multirow{3}{*}{$\begin{array}{l}\text { \%ofC } \\
18 \\
\end{array}$} \\
\hline & & \multicolumn{18}{|c|}{2012} & \multirow{2}{*}{\multicolumn{2}{|c|}{ TRA }} & \\
\hline & & \multirow{2}{*}{ IEE } & \multicolumn{4}{|c|}{ SEFU } & \multirow{2}{*}{ GAD } & \multicolumn{4}{|c|}{ PDAF } & \multicolumn{4}{|c|}{ IRA } & \multicolumn{4}{|c|}{ DRRM } & & & \\
\hline & LGUs & & 1 & 2 & 3 & 4 & & 1 & 2 & 3 & 4 & 1 & 2 & 3 & 4 & 1 & 2 & 3 & 4 & \multicolumn{2}{|l|}{2012} & \\
\hline 1 & Asuncion & 1 & 1 & 1 & 1 & 1 & 1 & 1 & 1 & 1 & 1 & 0 & 0 & 0 & 1 & 1 & 1 & 1 & 1 & 15 & $83 \%$ & \\
\hline 2 & Carmen & 1 & 1 & 1 & 1 & 1 & 1 & 1 & 1 & 1 & 1 & 1 & 1 & 1 & 1 & 1 & 1 & 1 & 1 & 18 & $100 \%$ & \\
\hline 3 & Dujali & 1 & 1 & 1 & 1 & 1 & 1 & 1 & 1 & 1 & 1 & 1 & 1 & 1 & 1 & 1 & 1 & 1 & 1 & 18 & $100 \%$ & \\
\hline 4 & Kapalong & 1 & 1 & 0 & 0 & 0 & 0 & 0 & 0 & 0 & 0 & 1 & 1 & 1 & 0 & 1 & 1 & 1 & 1 & 9 & $50 \%$ & \\
\hline 5 & New Corella & 1 & 1 & 1 & 1 & 1 & 1 & 0 & 0 & 1 & 1 & 1 & 1 & 1 & 0 & 1 & 1 & 1 & 1 & 15 & $83 \%$ & \\
\hline 6 & Panabo & 1 & 1 & 1 & 1 & 1 & 1 & 1 & 1 & 1 & 1 & 1 & 1 & 1 & 1 & 1 & 1 & 1 & 1 & 18 & $100 \%$ & \\
\hline 7 & Samal & 1 & 1 & 1 & 1 & 1 & 1 & 1 & 1 & 1 & 1 & 1 & 1 & 1 & 1 & 1 & 1 & 1 & 1 & 18 & $100 \%$ & \\
\hline 8 & San Isidro & 1 & 0 & 0 & 0 & 1 & 0 & 0 & 0 & 0 & 1 & 1 & 1 & 1 & 1 & 0 & 0 & 0 & 1 & 8 & $44 \%$ & \\
\hline 9 & Sto. Tomas & 1 & 0 & 0 & 1 & 1 & 1 & 0 & 0 & 1 & 0 & 0 & 0 & 1 & 1 & 0 & 0 & 0 & 1 & 8 & $44 \%$ & \\
\hline 10 & Tagum & 1 & 1 & 1 & 1 & 1 & 1 & 1 & 1 & 1 & 1 & 1 & 1 & 1 & 1 & 1 & 1 & 1 & 1 & 18 & $100 \%$ & \\
\hline 11 & Talaingod & 1 & 1 & 1 & 1 & 1 & 1 & 1 & 1 & 1 & 1 & 1 & 1 & 1 & 1 & 1 & 1 & 1 & 1 & 18 & $100 \%$ & \\
\hline & Total & 11 & 9 & 8 & 9 & 10 & 9 & 7 & 7 & 9 & 9 & 9 & 9 & 10 & 9 & 9 & 9 & 9 & 11 & 163 & $82 \%$ & \\
\hline
\end{tabular}

Legend:

IEE SEF Income and Expenditures Estimates

SEFU SEF Utilization

GAD Annual GAD Accomplishment Report

PDAF Trust Fund Utilization

IIRA 20\%Component of the IRA Utilization

DRRM Local DRRM Fund Utilization

TRA Total Reports Available

\% ofC Percentage of Compliance

For the year 2013, the compliance of all the LGUs in posting the required Special Purpose Fund Reports is increasing. In fact, 8 out of 11 LGUs were able to provide all the 18 reports to be made available at the portal, thus $100 \%$ compliance was computed. Only the city of Tagum and the municipalities of Talaingod and Kapalong were not able to upload completely the required documents on that year having the respective compliance percentages: $94 \%$, $89 \%$ and $28 \%$ (see Table 6). 
Table 6. Special Purpose Fund Reports Available at the FDP Portal, 2013

\begin{tabular}{|c|c|c|c|c|c|c|c|c|c|c|c|c|c|c|c|c|c|c|c|c|c|}
\hline & \multirow[b]{4}{*}{ LGUs } & \multicolumn{18}{|c|}{ SPECIAL PURPOSE FUND REPORTS } & \multirow[b]{3}{*}{ TRA } & \multirow{3}{*}{$\begin{array}{l}\text { \%ofC } \\
18\end{array}$} \\
\hline & & \multicolumn{18}{|c|}{2013} & & \\
\hline & & \multirow{2}{*}{ IEE } & \multicolumn{4}{|c|}{ SEFU } & \multirow{2}{*}{ GAD } & \multicolumn{4}{|c|}{ PDAF } & \multicolumn{4}{|c|}{ IRA } & \multicolumn{4}{|c|}{ DRRM } & & \\
\hline & & & 1 & 2 & 3 & 4 & & 1 & 2 & 3 & 4 & 1 & 2 & 3 & 4 & 1 & 2 & 3 & 4 & 2013 & \\
\hline 1 & Asuncion & 1 & 1 & 1 & 1 & 1 & 1 & 1 & 1 & 1 & 1 & 1 & 1 & 1 & 1 & 1 & 1 & 1 & 1 & 18 & $100 \%$ \\
\hline 2 & Carmen & 1 & 1 & 1 & 1 & 1 & 1 & 1 & 1 & 1 & 1 & 1 & 1 & 1 & 1 & 1 & 1 & 1 & 1 & 18 & $100 \%$ \\
\hline 3 & Dujali & 1 & 1 & 1 & 1 & 1 & 1 & 1 & 1 & 1 & 1 & 1 & 1 & 1 & 1 & 1 & 1 & 1 & 1 & 18 & $100 \%$ \\
\hline 4 & Kapalong & 1 & 0 & 1 & 1 & 0 & 1 & 0 & 1 & 0 & 0 & 0 & 0 & 0 & 0 & 0 & 0 & 0 & 0 & 5 & $28 \%$ \\
\hline 5 & New Corella & 1 & 1 & 1 & 1 & 1 & 1 & 1 & 1 & 1 & 1 & 1 & 1 & 1 & 1 & 1 & 1 & 1 & 1 & 18 & $100 \%$ \\
\hline 6 & Panabo & 1 & 1 & 1 & 1 & 1 & 1 & 1 & 1 & 1 & 1 & 1 & 1 & 1 & 1 & 1 & 1 & 1 & 1 & 18 & $100 \%$ \\
\hline 7 & Samal & 1 & 1 & 1 & 1 & 1 & 1 & 1 & 1 & 1 & 1 & 1 & 1 & 1 & 1 & 1 & 1 & 1 & 1 & 18 & $100 \%$ \\
\hline 8 & San Isidro & 1 & 1 & 1 & 1 & 1 & 1 & 1 & 1 & 1 & 1 & 1 & 1 & 1 & 1 & 1 & 1 & 1 & 1 & 18 & $100 \%$ \\
\hline 9 & Sto. Tomas & 1 & 1 & 1 & 1 & 1 & 1 & 1 & 1 & 1 & 1 & 1 & 1 & 1 & 1 & 1 & 1 & 1 & 1 & 18 & $100 \%$ \\
\hline 10 & Tagum & 1 & 1 & 1 & 1 & 1 & 1 & 1 & 1 & 0 & 1 & 1 & 1 & 1 & 1 & 1 & 1 & 1 & 1 & 17 & $94 \%$ \\
\hline 11 & Talaingod & 1 & 1 & 1 & 1 & 0 & 1 & 1 & 1 & 1 & 1 & 1 & 1 & 1 & 0 & 1 & 1 & 1 & 1 & 16 & $89 \%$ \\
\hline & Total & 11 & 10 & 11 & 11 & 9 & 11 & 10 & 11 & 9 & 10 & 10 & 10 & 10 & 9 & 10 & 10 & 10 & 10 & 182 & $92 \%$ \\
\hline
\end{tabular}

It is remarkable also that there some specific reports which were completely made available by the LGUs to list: the SEF Income and Expenditures Estimates and the Gender and Development Accomplishment Report which are to be posted once a year and the last two quarters report for the SEF Utilization and the second quarter report of the Trust Fund Utilization. In totality, the percentage of compliance of the LGUs in posting the required Special Purpose Fund Reports is notably $92 \%$.

The LGUs which posted information to the public relating the above reports clearly indicates that the government of the cities is open to facilitate an open government accessibly made available to the public. This result is similar to the countries of Middle East and South Africa, where most of the contents and features in their websites are relating to the concerning contents (Demissie, et al., 2010).

Figure 6 shows the comparative compliance of the LGUs in the year 2012 and 2013 in posting the Special Purpose Fund Reports. As can be seen, the compliance is increasing except for the city of Tagum and the municipalities of Kapalong and Talaingod. Even by that, in totality there is an increase of compliance from 2012 having $82 \%$ to $92 \%$ in the year 2013 .

In Figure 7, among the concerning LGUs, the municipalities of Carmen and Dujali as well as the cities of Panabo and Samal got a $100 \%$ as the overall compliance in posting the Special Purpose fund Reports. This is followed by is the city of Tagum which complies $97 \%$ of the required reports, then the municipality of Talaingod for complying $94 \%$. The municipalities of Asuncion and New Corella complied 92\%, then San Isidro and Sto. Tomas complied 72\% and the municipality of Kapalong complied $39 \%$. To sum up, a rate of $87 \%$ is the compliance percentage of all the LGUs in posting the relevant reports from $2012-2013$. 


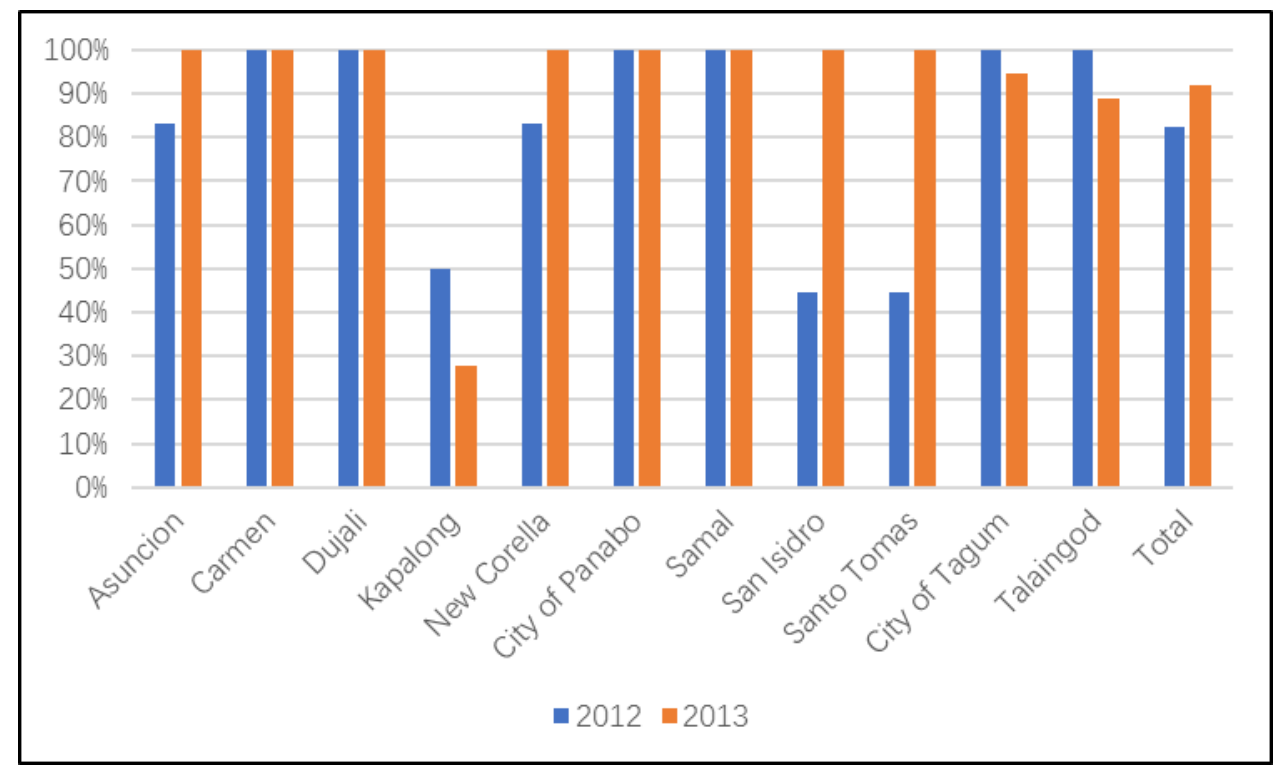

Figure 6. Comparison on Special Purpose Fund Reports Compliance, 2012-2013

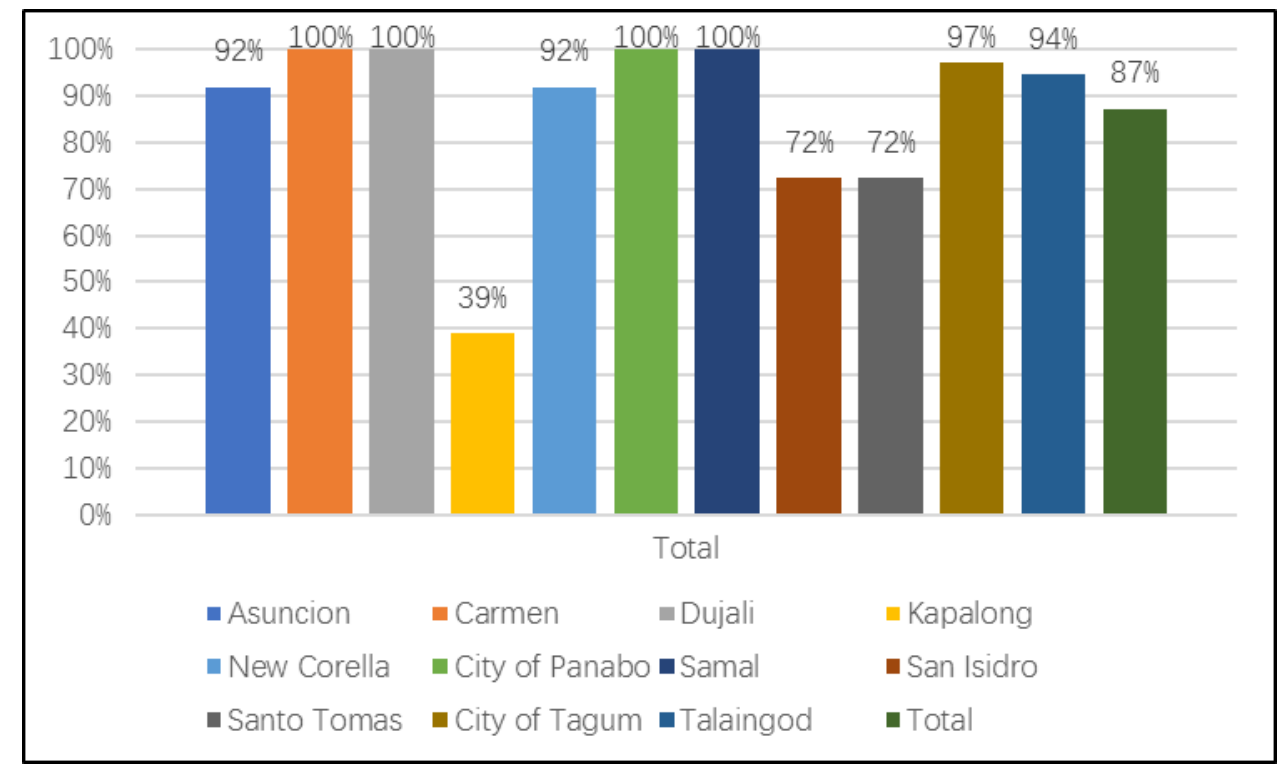

Figure 7. Overall Special Purpose Fund Reports Compliance

\section{LGUs' Compliance in Posting FDP Reports}

In this particular section, discussions regarding the overall compliance of the concerning LGUs in the Province of Davao del Norte in posting the Budget Reports, Procurement Reports and Special Purpose Fund Reports at the FDP portal were tackled.

Table 7depicts the percentage of compliance of the LGUs in all the inquired reports in the year 2012. As it can be seen, 5 LGUs were able to upload all the 38 required FDP reports for the year 2012 and these were the municipalities of Carmen, Dujali and the cities of Panabo, Samal and Tagum for obtaining 100\% compliance. To add with, Talaingod got $89 \%$ while the LGUs of Asuncion and New Corella both obtained 87\%, Kapalong complies 61\% whereas Sto. Tomas and San Isidro has a compliance percentage of $37 \%$ and $32 \%$ respectively. An 
average of $81 \%$ was computed as the overall compliance of the LGUs in posting all the FDP required reports at the FDP portal in the year 2012.

These results affirmed the idea that the availability of the downloadable reports as posted in the web portal brought visible convenience to the citizens since they can eventually access it 24 hours in a day, 7 days in a week (Reddick,2004); this entails lessening of the cost and could hasten interaction in availing it. These results likewise echo Hood (1991), Pollitt and Bouckaert (2000) and Kettl (2002) as cited by Siar (2007), who said that as the LGUs make the information and documents queried available, this promotes effective and efficient service delivery to the public.

Table 7. FDP Reports Compliance, 2012

\begin{tabular}{|c|c|c|c|c|c|c|}
\hline & \multirow[b]{3}{*}{ LGUs } & \multicolumn{4}{|c|}{2012} & \multirow[b]{3}{*}{ \%ofC } \\
\hline & & \multirow{2}{*}{$\begin{array}{l}\mathrm{BR} \\
7 \\
\end{array}$} & \multirow{2}{*}{$\frac{P R}{13}$} & \multirow{2}{*}{$\begin{array}{l}\text { SPFR } \\
18\end{array}$} & \multirow{2}{*}{$\begin{array}{l}\text { Total } \\
\mathbf{3 8} \\
\end{array}$} & \\
\hline & & & & & & \\
\hline 1 & Asuncion & 7 & 11 & 15 & 33 & $87 \%$ \\
\hline 2 & Carmen & 7 & 13 & 18 & 38 & $100 \%$ \\
\hline 3 & Dujali & 7 & 13 & 18 & 38 & $100 \%$ \\
\hline 4 & Kapalong & 5 & 9 & 9 & 23 & $61 \%$ \\
\hline 5 & New Corella & 7 & 11 & 15 & 33 & $87 \%$ \\
\hline 6 & Panabo & 7 & 13 & 18 & 38 & $100 \%$ \\
\hline 7 & Samal & 7 & 13 & 18 & 38 & $100 \%$ \\
\hline 8 & San Isidro & 3 & 1 & 8 & 12 & $32 \%$ \\
\hline 9 & Sto. Tomas & 4 & 2 & 8 & 14 & $37 \%$ \\
\hline 10 & Tagum & 7 & 13 & 18 & 38 & $100 \%$ \\
\hline \multirow[t]{2}{*}{11} & Talaingod & 7 & 9 & 18 & 34 & $89 \%$ \\
\hline & Total & 68 & 108 & 163 & 339 & $81 \%$ \\
\hline
\end{tabular}

Legend

BR Budget Reports

$\boldsymbol{P R} \quad$ Procurement Reports

SPFR Special Purpose Fund Reports

Presented in Table 8 is the overall compliance of the 11 LGUs in posting all the required FDP reports at the FDP portal for the year 2013. None of the LGUs were able to completely upload the inquired 38 documents at the portal. Five LGUs to name: Dujali, Panabo and Samal got the highest compliance percentage equating to 95\%. It was followed by the LGUs of New Corella, and Tagum having 92\% compliance rating then Asuncion, Carmen and Talaingod for complying $89 \%$ of the reports, Sto.Tomas and Kapalong got a respective rating of $87 \%$ and $42 \%$. The overall compliance percentage of the LGUs in the Province of Davao del Norte in posting all the FDP reports at the portal for the year 2013 is $87 \%$. 


\section{Macrothink}

Table 8. FDP Reports Compliance, 2013

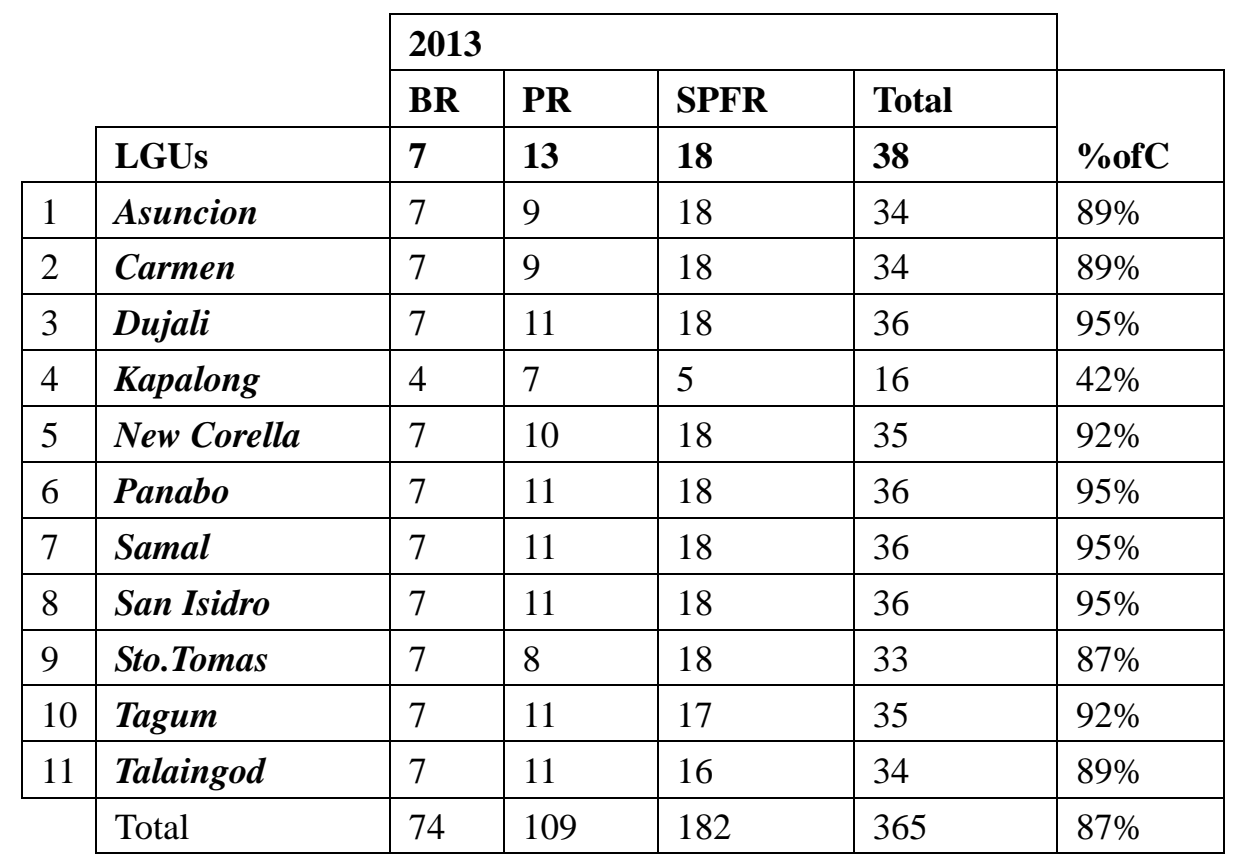

Though there were no LGU which completely made all the inquired FDP reports for the year 2013 available, the above discussions reveal that there is still an increase of compliance percentage averagely. As can be referred in Figure 8, the overall compliance rating of the LGUs for the year 2012 and 2013 is equating to 84\%. Dujali, Panabo and Samal were the most compliant LGUs obtaining $97 \%$ or 74 out of 76 inquired reports. Next is Tagum for complying 96\%, Carmen complies 95\%, followed by New Corella and Talaingod which both complies 89\%, then San Isidro, Sto. Tomas and Kapalong for obtaining the following respective compliance percentages: $63 \%, 62 \%$ and $51 \%$.

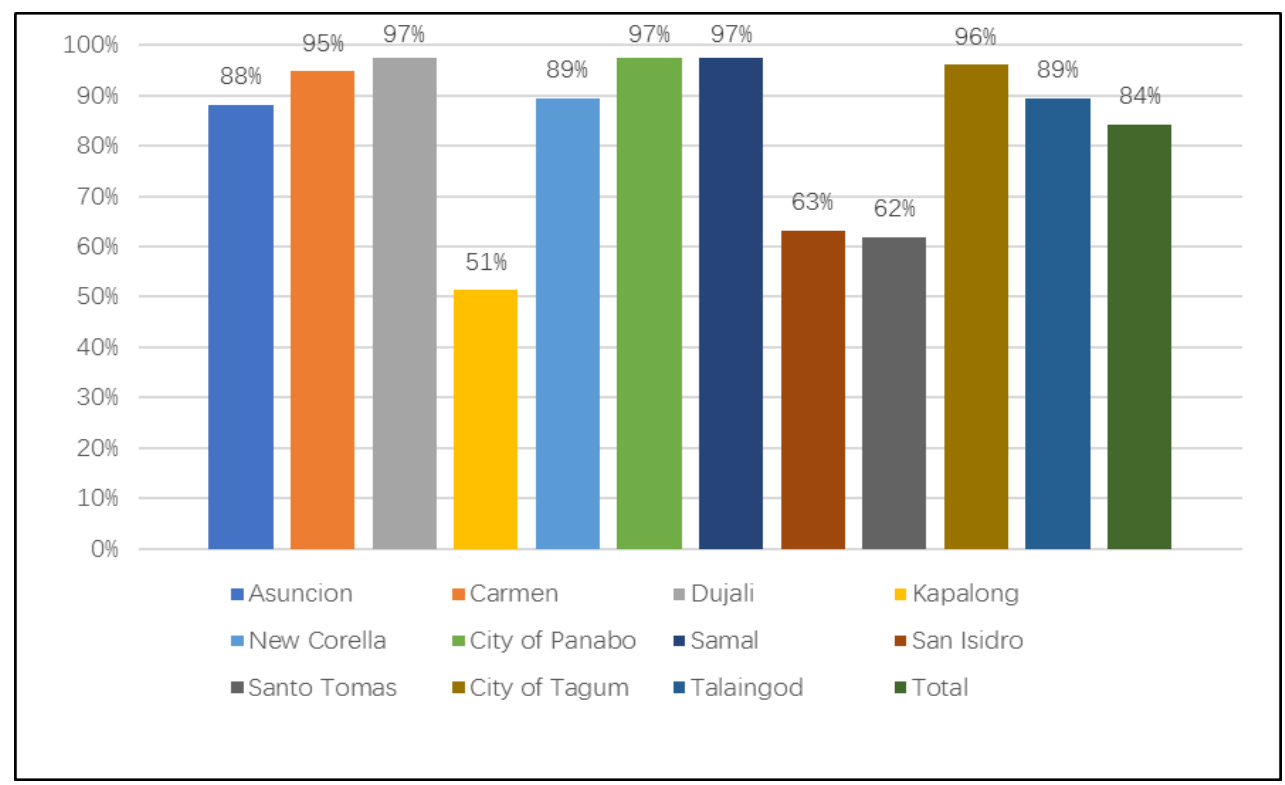

Figure 8. Overall Compliance in Posting FDP Reports, 2012-2013 


\section{MInstitute Macrothink $^{m}$}

Journal of Public Administration and Governance ISSN 2161-7104 2017, Vol. 7, No. 3

Table 9 shows the percentage of compliance of all the specific FDP reports which were made available at the FDP portal by all the concerning LGUs in the Province of Davao del Norte. As it can be observed, 2 reports were completely uploaded by all the LGUs and these were the Statement of Receipts and Expenditures and the SEF Income and Expenditures Estimates. Next to most complied reports were the Annual Budget and Annual Procurement Plan for having 95\% availability of reports required, then the Annual GAD Accomplishment Report (91\%). Followed by the Quarterly Statement of cash Flows and Local DRMM Fund Utilization for the $89 \%$ available reports, SEF Utilization for having 88\%, $20 \%$ Component of IRA Utilization (86\%), Quarterly Bid Results on Civil Works, Goods and Services (84\%), Trust Fund Utilization (82\%). Some reports which were least complied are as follows: Abstract of Bids as Calculated for obtaining 75\% only of the reports required and Quarterly Items to Bid for the $64 \%$ available reports.

The use of the government web portal as a medium to promote transparency is observably utilized by the LGUs in the province of Davao del Norte. This practice affirms President Barack Obama of USA who believes that openness will strengthen democracy and promote efficiency and effectiveness in government. However, to achieve increase transparency which decreases corruption is not possible without incorporating appropriate channels for public feedback (UNDP, 2005).

Table 9. FDP Reports Availability, 2012-2013

\begin{tabular}{|c|c|c|c|c|c|c|c|}
\hline \multirow[b]{2}{*}{ FDP Reports } & \multicolumn{2}{|l|}{ TRR } & \multicolumn{2}{|l|}{ TRA } & \multicolumn{2}{|c|}{ \% of Compliance } & \multirow[b]{2}{*}{ Overall } \\
\hline & 2012 & 2013 & 2012 & 2013 & 2012 & 2013 & \\
\hline$A B$ & 11 & 11 & 10 & 11 & $91 \%$ & $100 \%$ & $95 \%$ \\
\hline$S D S$ & 11 & 11 & 10 & 11 & $91 \%$ & $100 \%$ & $95 \%$ \\
\hline$S R E$ & 11 & 11 & 11 & 11 & $100 \%$ & $100 \%$ & $100 \%$ \\
\hline$S C F$ & 44 & 44 & 37 & 41 & $84 \%$ & $93 \%$ & $89 \%$ \\
\hline$A P P$ & 11 & 11 & 10 & 11 & $91 \%$ & $100 \%$ & $95 \%$ \\
\hline$I T B$ & 44 & 44 & 26 & 30 & $59 \%$ & $68 \%$ & $64 \%$ \\
\hline$B R$ & 44 & 44 & 35 & 39 & $80 \%$ & $89 \%$ & $84 \%$ \\
\hline$A B C$ & 44 & 44 & 37 & 29 & $84 \%$ & $66 \%$ & $75 \%$ \\
\hline$I E E$ & 11 & 11 & 11 & 11 & $100 \%$ & $100 \%$ & $100 \%$ \\
\hline SEFU & 44 & 44 & 36 & 41 & $82 \%$ & $93 \%$ & $\mathbf{8 8 \%}$ \\
\hline$G A D$ & 11 & 11 & 9 & 11 & $82 \%$ & $100 \%$ & $91 \%$ \\
\hline PDAF & 44 & 44 & 32 & 40 & $73 \%$ & $91 \%$ & $82 \%$ \\
\hline$I R A$ & 44 & 44 & 37 & 39 & $84 \%$ & $89 \%$ & $86 \%$ \\
\hline DRRM & 44 & 44 & 38 & 40 & $86 \%$ & $91 \%$ & $89 \%$ \\
\hline
\end{tabular}

Legend:
AB
Annual Budget
SDS
Statement of Debt Services 


$\begin{array}{ll}\text { SRE } & \text { Statement of Receipts and Expenditures } \\ \text { SCF } & \text { Quarterly Statement of Cash Flows } \\ \text { APP } & \text { Annual Procurement Plan } \\ \text { ITB } & \text { Quarterly Items to Bid } \\ \text { BR } & \text { Quarterly Bid Results on Civil Works, Goods and Services } \\ \text { ABC } & \text { Quarterly Abstract of Bids as Calculated } \\ \text { IEE } & \text { SEF Income and Expenditures Estimates } \\ \text { SEFU } & \text { SEF Utilization } \\ \text { GAD } & \text { Annual GAD Accomplishment Report } \\ \text { PDAF } & \text { Trust Fund Utilization } \\ \text { IRA } & \text { 20\%Component of the IRA Utilization } \\ \text { DRRM } & \text { Local DRRM Fund Utilization } \\ \text { TRR } & \text { Total Reports Required } \\ \text { TRA } & \text { Total Reports Available } \\ \text { \%ofC } & \text { Percentage of Compliance }\end{array}$

\section{Summary, Conclusions and Recommendations}

\section{Summary and Conclusion}

Based on the findings of the study, the summative discussions as to the generalization in the conduct of the study as well as several conclusions were drawn as presented in the subsequent discussions.

This is an evaluative study which assessed the e-Governance implementation of all the municipalities and cities in the province of Davao del Norte via government web portal as their medium. The study investigated if the concerning LGUs were compliant in posting the 13 required documents queried as required by the FDP to be made available in the FDP portal.

Several related literatures and studies were utilized to substantiate the outcome derived in the study. In the conduct of the study, an initial investigation was made by the MPA students under the subject PA 504 - Management Communication through looking in the government web portal of DILG where FDP reports should be uploaded and this is accessible through the URL address at http://fdpp.blgs.gov.ph/. To triangulate the data, the researchers per se did the checking of the available reports uploaded at the portal by the LGUs.

Secondary data was obtained by looking into the availability of the reports uploaded at the FDP portal. Frequency counts, means and percent were used in analyzing the data collected. Based on the results of the evaluation and data gathered, the following findings were obtained:

For the Budget Reports, there is an increase of compliance in posting the required relevant reports at the FDP portal in the year 2013 in compare from the previous year. There is a computed $8 \%$ increase of compliance from 2012 which is $88 \%$ to $96 \%$ for the year 2013 which obtained an average compliance of $92 \%$. The same situation is for the Special Purpose Fund Reports, since there is an increase of $10 \%$ as compliance for the $82 \%$ in the year 2012 
to $92 \%$ of compliance for the year after. The above scenario is not akin in terms of making available of the Procurement Reports, since a percentage of $76 \%$ is computed both for the year 2012 and 201, thus there is the same percentage of compliance.

As to the compliance of the specific LGUs, there is an increase of compliance percentage from 2012 to 2013 for the LGUs of Asuncion, New Corella, San Isidro and Sto. Tomas whereas the rest of the LGUs there is noticeably slight decrease of compliance. Overall, in getting the average compliance for the year 2012 and 2013, the most compliant LGUs were as follows: Dujali, Panabo and Samal for uploading $97 \%$ of the required reports.

In dealing with the specific FPD reports, the most complied reports were the Statement of Receipts and Expenditures and the SEF Income and Expenditures Estimates wherein 100\% of the required reports were made available by all the LGUs; whereas, the least complied is the Quarterly Items to Bid for the 64\% availability.

To conclude, though it can be said that the LGUs are exerting effort in making available of the required documents as posting it on the web portal, it is visible that there are some underlying forces which hinders the concerning LGUs to attain full complaint on the said policy. The following are the hypotheses of the authors as to the factors affecting the compliance of the LGUs:

Digital Divide. The most obvious factor which can be considered as a predicament of the LGUs in fulfilling the attainment of uploading the documents at the web portal is the unavailability of technology to facilitate the transactions and this includes the internet connection not to mention the distance of the concerning LGUs which could hinder the availability of such. It is supposed that the administrators of the LGUs considered acquiring an internet service provider which is most suitable to be acquired considering access and distance.

Documents Tracking. It is somewhat debatable that there are documents which are not available where in fact same documents were uploaded on the next posting. This scenario could be attributable to the proper keeping of those documents in which ideally, there should be a database which comprises the relevant documents wherein must be updated and facilitated by qualified personnel knowledgeable enough in the process of storing properly those data.

IT Experts and Services. Late submission of documents or unavailability of the required documents could be due because of lack of equipment which is required to facilitate its preparation. Such knowledge also of the personnel assigned as to the literacy in handling computer operations can also be considered as a factor in attaining compliance. Preferably, LGUs must be equipped with enough computer units to expedite the preparation and compilation of the required documents considering also the presence of an end-user which is capable and knowledgeable enough in handling processes and transactions when it comes to preparing and uploading the documents at the portal.

Policy Dissemination. Full Disclosure Policy is no longer a raw policy. It has been implemented since 2010 though the requirements of posting the documents at the web portal 
was applied last 2012. The policy is supposed to be disseminated not just to the concerning personnel who take charge in the submission and uploading of the documents but as well as to the personnel involved in its preparation. Employees of the LGUs must have to be aware regarding the possible awards and rewards their LGUs could obtain in case compliance of the FDP is fulfilled, by that they can work together in order to provide the required data to fulfill the compliance of the policy.

\section{Recommendations}

Out from the results generated from the study and from the abovementioned hypotheses as part of deriving the conclusion, there are two parts of recommendations formulated: $\left(1^{\text {st }}\right)$ those which can be considered for the usual compliance of the concerning LGUs for the Full Disclosure Policy and $\left(2^{\text {nd }}\right)$ policy recommendation wherein once adopted, could improve and enrich the process and transaction of any LGUs in the country in the practice of e-Governance.

\section{Part 1. Further Compliance}

1. Concerned LGUs should increase its compliance in posting the required FDP reports at the FDP portal most specifically for the relevant Procurement Reports since notably, among the categorized FDP reports, it is the least complied.

2. Constant monitoring and rechecking of the uploaded reports should be done in the case there were reports which were not successfully uploaded since it has been found specially in the reports which are to be posted quarterly, there are some LGUs wherein reports were not completely available.

3. Since the focus of this study is the assessment of the available reports uploaded in the FDP portal which leads to the comparative discussions as to the compliance of the concerning LGUs. Though the study was able to identify the lacking reports which are supposed to be uploaded at the FDP portal, it overlooked the factors affecting the compliance of the LGUs such as distance and income classification, the promptness in submitting, uploading and or making available of the FDP reports not just in the portal but also in some other conspicuous places where the reports should be seen, the awareness of the respective citizens in the relevant FDP reports as well as in looking the available reports at the FDP portal. Hence, it is recommended by the researchers that future research be conducted this time on the said indicators.

\section{Part 2. Policy Recommendation}

Ease and accessibility of government information and services for citizens and other government organizations and sectors is an aid in promoting good governance. But such improvement greatly depends on government's unit budget. To boost e-Governance capability and to foster compliance in implementing Full Disclosure Policy, allocation of budgetary requirements to sustain such practice is proportionally required to facilitate effective and efficient transactions and processes. Hence, the step by step policy recommendations as listed below are hereby stated for the concerning LGUs which will mandate provision of approach in implementing e-Government services: 
1. Organization of an IT Department. Local Chief Executives of the LGUs should initiate the idea of electronic management system which can be best realized if there is acapable and knowledgeableIT head in a department wherein IT services are offered. The idea of giving a plantilla positions to the needed staff can also be considered since there is a need for the IT department to comprise competent staff to properly establish ICT activities of the LGUs such as provision of a system to automate certain transactions and processes and updating and maintaining web services.

2. Restructuring of the IT Service Delivery. There is a need to improve the availability of equipment to fasten the provision of services and to facilitate the transaction orderly and accessibility of the internet services in order to possibly comply the uploading of documents at the portal. This could be done by positively looking into transforming the usual manual processes provided as part of the service delivery to an automated one which could contribute to a more effective and efficient output delivery. Another is the consideration of the internet service provider suitable to acquire in terms of providing access while considering the distance.

3. ICT Capability Training of the Human Resource. Human capital as the most important resource must be taken for consideration especially when it comes to updating and enhancing their skills towards giving service to the general public. LGUs should strive attaining towards computer literacy of their employees as it is known how advantageous is the utilization of ICT in providing service delivery to the general public. The goal is to have a competent employee when it comes to handling computer operations; adequate enough to facilitate the transactions involved especially in administering web services. Thus, constant provision of trainings and skills assessment for all levels of employees must be spearheaded.

4. Implementation of Information Data Mining. Personnel involved in the appropriate keeping of vital documents of LGU must practice complying recordkeeping either in electronic or paper records. IT department should initiate appropriate keeping of those important documents to be established in a database where can be accessed anytime and anywhere in a most convenient way. Applying information data mining would serve as an advantage to the LGU when it comes to ensuring that the data gathered are safe and can be obtained anytime.

5. Giving of recognition and incentives. As part of compliance in the Full Disclosure Policy, it is known that this could be one of the criteria in achieving the Seal of Good Local Governance. In attaining such, a reward and incentive will be given to the compliant LGU. As such, it is best to recognize the effort exerted of the workforce behind the successful implementation and give due credit by giving awards or any form of compensatory reward. 


\section{References}

Affisco, J., \& Soliman, K. (2006). e-Government: A strategic operations management frameworkfor service delivery. Business Process Management Journal, 12, 13-21. https://doi.org/10.1108/14637150610643724

Al-adawi, Z., Yousafzai, S., \& Pallister, J. (2005). Conceptual model of citizen adoption of e-government. The Second International Conference on Innovationsin Information Technology. $\quad$ Retrieved March 11, 2013, from http://www.itinnovations.ae/iit005/proceedings/articles/G_6_IIT05-Al-Adawi.pdf

Cordon, J. C. (2010). Budget Transparency Limited to Few People. Retrieved December 18,2012 from Manila Times cited by the Trade Union Congress of the Philippines Web site: http://www.tucp.org.ph/news/index.php/2010/10/budget-transparency-limited-to-few-people/

Davao Region Regional Development Research Agenda. (2011-2016). Part 3: Governance Priority Research Agenda, pg. 33.

Demissie, A., et. al (2010). A Comparative Study of Contents of e-Government Service Websites of Middle East and North African (MENA) Countries. C.G Reddick (ed.), Comparative e-Government, Integrated Series in Information. Retrieved March 12, 2013 from University of Tennessee Web site: http://works.bepress.com/devendra_potnis/8/

Epal and Linden. (2010). PTF Case Study Series No. 20. Organizing and Sustaining Civil Society-led Procurement in the Philippines from Partnership for Transparency Fund.

Farhan, H., \& Sanderson, M. (2007). Measuring the Quality of E_Government Folksonomy. Retrieved January 18,2013 from Department of Information Studies University of Sheffield Web site: http://www.seg.rmit.edu.au/mark/../my.../e-Government_Folksonomy.pdf

Hill, Hermann (n.d). Citizen Participation and New Perspectives in the Multimedia Era. Retrieved date March 13,2013 at www.dhv-speyer.de/hill/Publikationen/Citizen.pdf

Irvin, R., \& Stansbury, J. (2004). Citizen participation in Decision Making: Is it Worth the Effort?

Lallana, E. et al. (2002). e-Government in the Philippines: Benchmarking Against Global Practices. Retrieved January 17, 2013 from Digital Philippines Web site: http://www.digitalphilippines.org

National Higher Education Research Agenda - 2 (2009 - 2018).

Oates, B. (2003). The Potential Contribution of ICTs to the Political Process. Electronic Journal of e-Government Volume 1 Issue 1, 2003(pp 31-39). Retrieved January 8, 2012, from http://www.ejeg.com/issue/download.html?idArticle=216

Obama. (2009). Open Government Initiative. Retrieved date March 13,2013 at www.whitehouse/gov/open

Ong, C. Z. (2012). Jesse's Crown Jewel: Full Disclosure Policy. Retrieved August 7, 2014 


\section{Macrothink}

Journal of Public Administration and Governance ISSN 2161-7104 2017, Vol. 7, No. 3

from Manila Bulletin Publishing Corporation Web site: http:// mb.com.ph/articles/370486/jesse-s-crown-jewel-full-disclosure-policy\#. UM_2F3fheSo

Phillips, D. (2001). Online public relations, Kogan Page Limited, London.PIA Press Release (2011, October 20). City of Tagum Lauded for Excellent Governance

Reddick, C. (2004). Citizen Interaction with e-Government: From the Streets to Servers?. Government Information Quarterly 22 (2005) 38-57. Retrieved March 13, 2013 from Department of Public Administration, The University of Texas Web site: https://docs.google.com. https://doi.org/10.1016/j.giq.2004.10.003

UN e-Government Survey. (2010). The State of e-Government around the World (Part 2). Retrieved date: August 7, 2014 at https://docs.google.com

You and Lee. (2011). Budget Transparency and Participation- Korean Case Study Philippine Development Plan (2011-2016).

You and Lee (2011). Budget Transparency and Participation- Korean Case Study.

\section{Copyright Disclaimer}

Copyright for this article is retained by the author(s), with first publication rights granted to the journal.

This is an open-access article distributed under the terms and conditions of the Creative Commons Attribution license (http://creativecommons.org/licenses/by/4.0/). 